DOI https://doi.org/10.18551/rjoas.2018-10.21

\title{
EFFECT OF SERVICE QUALITY ON PATIENTS' SATISFACTION IN NURDIN MEDICAL CENTER OF BOGOR REGENCY, INDONESIA
}

\author{
Ningsih Dewi Lestaria*, Ronny \\ Institute of Economic Science Perbanas Surabaya, Indonesia \\ *E-mail: dewil431@gmail.com
}

\begin{abstract}
This study aims to determine the relationship of independent variables (Reliability, Responsiveness, Assurance, Empathy and Physical Evidence) to dependent variable (Patient Satisfaction). The method used in this study is questionnaires distributed directly to respondents. The sampling technique is Simple Random Sampling as sample is taken from population randomly without considering the strata in the population. The present study uses 85 outpatient respondents. The findings indicate that: reliability partially had a significant effect on patient satisfaction, responsiveness partially had no significant effect on patient satisfaction, assurance partially had insignificant effect on patient satisfaction, empathy partially had no significant effect on Patient Satisfaction, and Physical Evidence partially had a significant effect on Patient Satisfaction. Reliability Variables, Responsiveness, Assurance, Empathy, Physical Evidence simultaneously had a significant effect on Patient Satisfaction at Nurdin Medical Center Clinic in Bogor Regency.
\end{abstract}

\section{KEY WORDS}

Service, quality, patient, satisfaction.

Today's health has become a main need for the community. For that reason, in order to support health for all citizens, there must be concrete efforts carried out, one of which is providing health facilities for the community, one of which is a health clinic. Clinic is an institution or institution whose main function is to provide health services to the community. The main task of the clinic is to implement health efforts in an efficient and effective manner with healing and recovery efforts carried out in a harmonious and integrated manner with efforts to improve and prevent and implement referral efforts.

Table 1 - Recapitalization of Patient Visits Report for March 26, 2017 - June 25, 2017

\begin{tabular}{|c|c|c|c|c|}
\hline No & Patient Status & 26 March - 25 April & 26 April - 25 May & 26 May - 25 June \\
\hline 1 & PT. Anggada & 14 & 7 & 8 \\
\hline 2 & PT. ASKI & 26 & 18 & 24 \\
\hline 3 & PT. Citra Abadi Sahaja & 12 & 5 & 8 \\
\hline 4 & PT. Daehan & 181 & 140 & 5 \\
\hline 5 & PT. GA Indonesia & 4 & 3 & 35 \\
\hline 6 & PT. Inkordan & 36 & - & 10 \\
\hline 7 & PT. OASIS & 6 & 62 & 31 \\
\hline 8 & PT. Mitraida & 77 & 14 & 190 \\
\hline 9 & PT. Serena & 2 & 213 & 66 \\
\hline 10 & PT. Super & 54 & 60 & 32 \\
\hline 11 & PT. Uni Makmur & 44 & 27 & 1.115 \\
\hline 12 & NMC Staff & 1.380 & 1.217 & 4.264 \\
\hline 13 & General & 5.027 & 4.288 & \\
\hline 14 & BPJS & & & \\
\hline
\end{tabular}

Source: NMC Clinic Patient Visit Data, processed.

Nurdin Medical Center is a private clinic located in Bogor Regency, where health services are provided in the form of outpatient services, inpatient services and Emergency services that include medical support services. In service industry, customer satisfaction is determined by employees who deal directly with customers. To maintain consumers, the 
clinic is required to always maintain consumer confidence by paying careful attention to the needs of consumers in an effort to fulfill the desires and expectations of the services provided. According to Handi Irawan (2002), satisfaction in interaction happens is when customers receive service, $70 \%$ depend on employee performance. So it can be concluded that the lack of quality of Nurdin Medical Center Clinic services is likely due to a lack of employee performance.

Table 1 shows that the main problem faced by NMC Clinic was services to patients. Based on data obtained from the Clinic administration, the list of patient visits is decreasing. Patient visits in March were quite high in one month but in April and May the number declined. Obviously the patient's decline was caused by a lack of services provided. In addition, there were complaints from patients regarding Nurdin Medical Center Clinic services.

Table 2 - Patient Complaints Data

\begin{tabular}{|l|l|}
\hline No & \multicolumn{1}{|c|}{ Complaint } \\
\hline 1 & Doctor is not cooperative. \\
\hline 2 & The front office section (cashier, registration) and nurse do not smile and not friendly. \\
\hline 3 & The pharmacist always says medicines run out and patients are advised to buy them outside. \\
\hline
\end{tabular}

Source: Attachments processed.

To improve services that meet patient expectations or satisfaction Nurdin Medical Center Clinic, further studies are needed on the effect of service quality on perceptions of patient satisfaction, so that the results obtained can be used as a basis for making strategies to improve patient satisfaction, especially for planning service improvement in providing service to patients at the clinic.

\section{METHODS OF RESEARCH}

This study uses questionnaires distributed directly to respondents. The sampling technique is Simple Random Sampling because the taking of sample members from the population is performed randomly without considering the existing strata in the population where the sample members are selected only for general poly because it is easy to reach and easily obtainable (Cooper \& Schindler, 2008). The sample in this study were 85 respondents and the respondents were outpatient of general poly. The basic concepts used in this study are 5 (five) dimensions of SERQUAL from Parasuraman et al in Tjiptono (2007), namely Reliability, Responsiveness (Assurance), Assurance, Empathy, and Physical Evidence ( Tangibles). Data analysis techniques used Descriptive Analysis, Multiple Linear Analysis, $\mathrm{F}$ Test and t Test.

\section{RESULTS OF STUDY}

Validity test is used to measure whether a questionnaire is valid or not. A questionnaire is said to be valid if the question in the questionnaire is able to reveal something measured by the questionnaire. The validity of this research was carried out by conducting bivariate correlations between each indicator score and the total construct score using the Pearson coefficient. If the number is significant from the total number of indicators $<0.05$, then it can be concluded that each question indicator is valid.

Table 3 - Effect of Service Quality on Patient Satisfaction (R2)

\begin{tabular}{|c|c|c|c|c|}
\hline Model & $\mathrm{R}$ & $\mathrm{R}$ Square & Adjusted R Square & Std. Error of the Estimate \\
\hline 1 &, $782^{\mathrm{a}}$ &, 612 &, 587 & 1,447 \\
\hline
\end{tabular}


Based on table 3 above, the $R$ square value $(R 2)$ is 0.612 which means that the effect of service quality on patient satisfaction is $61.2 \%$, while the remaining $38.8 \%$ is influenced by other factors.

Table 4 - Analysis of the Effect of Service Quality on Patient Satisfaction

\begin{tabular}{|l|l|l|l|l|l|}
\hline Model & Unstandardized Coefficient & Standardized Coefficients & t & Sig \\
\hline & $\mathrm{B}$ & Std. Error & & & \\
\hline (Constant) & $-4,497$ & 1.430 & & $-3,144$ &, 002 \\
\hline Total X1 &, 218 &, 091 &, 213 & 2,393 &, 019 \\
\hline Total X2 &, 153 &, 091 &, 215 & 1,687 &, 096 \\
\hline Total X3 &, 069 &, 081 &, 114 &, 858 &, 393 \\
\hline Total X4 &, 073 &, 086 &, 091 &, 846 &, 400 \\
\hline Total X5 &, 230 &, 051 & 4,488 &, 000 \\
\hline
\end{tabular}

According to the data Analysis of the Effect of service Quality on Patient Satisfaction (Table 4) was: Reliability (X1) has a significance level of $0.019>0.05$ which means that the Reliability variable (X1) has a significant effect on the variable Patient Satisfaction (Y), so Ho is rejected and $\mathrm{Hi}$ is accepted. Responsiveness $(X 2)$ has a significance level of $0.096>0.05$, which means that the Response Power variable (X2) does not significantly affect Patient Satisfaction $(\mathrm{Y})$ variable, so $\mathrm{Ho}$ is accepted and $\mathrm{Hi}$ is rejected. Assurance (X3) has a significance level of $0.393>0.05$ which means that the assurance variable (X3) does not significantly affect variable of Patient Satisfaction $(\mathrm{Y})$, then $\mathrm{Ho}$ is accepted and $\mathrm{Hi}$ is rejected. Empati (X4) has a significance level of $0.400>0.05$, which means that the Empathy (X4) variable does not significantly affect variable of Patient Satisfaction $(Y)$, so Ho is accepted and $\mathrm{Hi}$ is rejected. Physical Proof (X5) has a significance level of $0.00<0.05$ which means that the Physical Proof (X5) variable does not significantly affect variable of Patient Satisfaction $(\mathrm{Y})$, then $\mathrm{Ho}$ is rejected and $\mathrm{Hi}$ is accepted.

\section{DISCUSSION OF RESULTS}

Reliability variable partially has a significant effect on patient satisfaction in Nurdin Medical Center, Bogor Regency. The results of this study are not in line with the results of previous research conducted by Ambriani, et al (2014) which states that Reliability has no significant effect on Customer Satisfaction. Then in line with research conducted by Tahir M. Nisar, et al (2018) and Vinita Kaura (2015) which states that reliability has a significant effect on customer satisfaction.

Respondents' responses as a whole show agree on the variable indicators Reliability with an average of 3.8. Respondents who stated that they did not agree with procedures and services were patients with insurance. Patients with this insurance geographically are patients who live not far from the location but if they want to seek treatment they must show an insurance card or an introduction from each of their companies in collaboration with the Nurdin Medical Center Clinic. Unlike respondents with general patients, respondents needed convincing reliability from the Nurdin Medical Center Clinic. Because financially, these respondents spend their own capital to seek treatment.

The Influence of Response Power on Patient Satisfaction. The Responsiveness variable partially had no significant effect on Patient Satisfaction at the Nurdin Medical Center Clinic in Bogor Regency. The results of this study differ from previous studies conducted by Ambriani, et al (2014) which states that responsiveness has a significant effect on patient satisfaction. Our results are in line with previous research conducted by Utami, et al (2013) which partially shows that responsiveness has no significant effect on customer satisfaction. This research is not in line with research conducted by Tahir M. Nisar, et al (2018) and Vinita Kaura, et al (2015) which states that responsiveness has a significant effect on customer satisfaction.

Respondents' responses as a whole showed that they agreed on the indicator of the Response Rate variable with an average of 3.66. Overall, responsiveness has no significant 
effect on patient satisfaction because it is related to patient care. If the responsiveness is low, then the problem still allows it to be resolved quickly and accurately, so the patient will feel harmed and patient dissatisfaction will arise.

Effect of Assurance on Patient Satisfaction. This variable partially has no significant effect on Patient Satisfaction at Nurdin Medical Center Clinic in Bogor Regency. The results of this study are in line with previous research conducted by Ambriani et al (2014) which states that assurance have no significant effect on patient satisfaction. The present research is in line with the results of research conducted by Utami et al (2013) which states that assurance has no significant effect on patient satisfaction. However, it is not in line with research conducted by Ravichandran, et al (2010), Tahir M. Nasir, et al (2010), and Vinita Kaura, et al (2015) which states that assurance have a significant effect on Patient Satisfaction.

Respondents' responses as a whole indicate that they agree on the variable guarantee indicator with an average of 3.69. Overall Assurance has no significant effect on patient satisfaction. The patient has a perception that the Nurdin Medical Center Clinic has guaranteed that medical officers have the knowledge, ability and trustworthy characteristics in serving patients, always maintaining the privacy of their patients. So patients generally have no doubt about the assurance provided by the Nurdin Medical Center Clinic.

Effect of Empathy on Patient Satisfaction. Empathy variable partially has no significant effect on Patient Satisfaction in Nurdin Medical Center Bogor Regency Clinic. The results of this study are not in line with previous research conducted by Ambriani et al (2014), Utami et al (2013), Ravichandran, et al (2010), Tahir M. Nasir, et al (2018), Vinita Kaura, et al ( 2015) which states that Empathy has a significant effect on Customer Satisfaction.

Respondents' responses as a whole showed that they agreed on the indicator Empathy variable with an average of 3.7. The statement that disagrees with the empathy statement in giving special attention to the respondent, means to receive complaints about what the respondent feels, and the effort to establish good relations with the respondent. Respondents have a perception that there is an effort to establish a good relationship.

Overall Empathy has no significant effect on patient satisfaction. A good communication relationship is very important and very necessary can be in the form of communication intensity, ease of contact, or even the intensity of visits that need to be maintained. Communication links that can both understand the needs and desires of patients so that patients feel cared for.

Effect of Physical Evidence on Patient Satisfaction. Physical Evidence variable has a significant effect on Patient Satisfaction at Nurdin Medical Center Clinic in Bogor Regency. The results of this study are in line with previous research conducted by Ambriani, et al (2014), Utami, et al (2013), and Ravichandran, et al (2010), Tahir M. Nasir, et al (2018), and Vinita Kaura, et al (2015) which states that Physical Evidence has a significant effect on patient satisfaction.

Respondents agree on variable indicators with an average of 3.68. Overall Physical Evidence has a significant effect on patient satisfaction. Adequate facilities are very supportive and exist in building patient trust.Secara keseluruhan atas Bukti Fisik berpengaruh signifikan terhadap kepuasan pasien. Fasilitas yang memadai sangatlah penting hal ini merupakan pendukung dan eksistensi dalam membangun kepercayaan pasien.

Effect of Reliability, Responsiveness, Assurance, Empathy and Physical Evidence on Patient Satisfaction. These variables simultaneously have a significant effect on Patient Satisfaction at the Nurdin Medical Center Clinic in Bogor Regency. That is, based on the results of Test $F$ (Simultaneous Test) changes in patient satisfaction are influenced by the independent variables together, because it has a significance level of $0.00<0.05$ which means that $\mathrm{Ho}$ is rejected and $\mathrm{Hi}$ is accepted, this means the quality of the service consists from Reliability, Responsiveness, Assurance, Empathy, and Physical Evidence have a significant influence on Patient Satisfaction at the Nurdin Clinic in Bogor Regency. 
Service quality has a significant influence on patient satisfaction. As stated by Tjiptono (2002: 54) that quality has a close relationship with customer satisfaction. Quality provides an encouragement to consumers to establish strong ties with the company.

\section{CONCLUSION}

Based on research conducted by using questionnaire data distributed to 85 (eightyfive) respondents, the conclusions are as follows: Reliability had a significant positive effect on patients, responding variable had a positive and insignificant effect on Patient satisfaction, Assurance had no significant positive effect on patient satisfaction, Empathy had a positive and not significant effect on patient satisfaction, physical evidence variables had a significant positive effect on patient satisfaction. Reliability, Responsiveness, Assurance, Empathy and Physical Evidence variables had a significant positive effect on Patient Satisfaction at Nurdin Medical Center Clinic in Bogor Regency.

\section{REFERENCES}

1. Ambariani, Irawan, 2014. Pengaruh Kualitas Pelayanan Puskesmas Santun Lansia Pada Kepuasan Pasien Lanjut Usia Di Puskesmas Santun Lanjut Usia Kabupaten Bogor Jawa Barat. Dalam Jurnal IImiah IJEMC Vol. 01. Bogor: Universitas Padjadjaran.

2. Amelia, Ismanto, Lestari, 2013. Pengaruh Kualitas Pelayanan Terhadap Kepuasan Pasien(Studi Kasus Pasien Rawat Jalan di Unit Gawat Darurat Rumah Sakit Bhayangkara Pusat Pendidikan Brigade Mobile Watukosek). Dalam Jurnal IImiah JKMP Vol 01. Sidoarjo: Universitas Muhammadyah.

3. Bungin, Burhan, 2005. Metodologi Penelitian Kuantitatif Komunikasi, Ekonomi, dan Kebijakan Publik serta IImu-IImu Sosial Lainnya. Edisi Pertama, Cetakan Pertama. Jakarta: Prenada Media.

4. Daryanto, 2011. Sari Kuliah Manajemen Pemasaran. Bandung: PT Sarana Tutorial Nurani Sejahtera.

5. Ferdinand, A. 2006, Metode Penelitian Manajemen. Semarang: BP Undip.

6. Husein Umar. 2003. Metode Riset Bisnis. Jakarta: PT Gramedia Pustaka Utama.

7. Julita. 2001. Menuju Kepuasan Pelanggan Melalui Penciptaan Kualitas Pelayanan. Dalam Jurnal IImiah Manajemen dan Bisnis Vol 01. Sumut: Univ Muhammadiyah.

8. Kotler, P. dan G. Armstrong. 2008. Prinsip-prinsip Pemasaran. Jilid 1. Jakarta: Erlangga.

9. Kotler, Philip. 2007. Manajemen Pemasaran, Analisis Perencanaan, Pengendalian. Prentice Hall, Edisi Bahasa Indonesia, Jakarta: Salemba Empat.

10. Kotler, Philip. 2000. Marketing Management: Edisi Milenium, International Edition. New Jersey: Prentice Hall International, Inc.

11. Kuncoro, Mudrajad. 2003. Metode Riset untuk Bisnis dan Ekonomi. Jakarta: Erlangga.

12. Likumahua, Debby. 2010. Faktor Kualitas Layanan serta Pengaruhnya Terhadap Kepuasan dan Loyalotas Nasabah Perbankan di Ambon. Surabaya: STIE Perbanas.

13. Lupiyoadi, Hamdani. 2006. Manajemen Pemasaran Jasa, Edisi Kedua. Jakarta: Penerbit Salemba Empat.

14. Mariotti, J, 2003. Marketing. Jakarta: Prestasi Pustaka Jaya

15. Muli , 2009. Pengaruh Kualitas Pelayanan Kesehatan Terhadap Kepuasan Pasien Rawat Inap Di Puskesmas Kota Medan. Medan: Universitas Sumatera Utara.

16. Rangkuti, Freddy, 2007. Riset Pemasaran. Cetakan Kelima. Jakarta: PT. Gramedia Pustaka Utama.

17. Ravichandran, K, Manil, Umar, 2010. Influence of Service Quality on Customer Satisfaction Application of Service quality Model. International Journal vol. 5. No. 4; April 2010. India.

18. Ridwan, 2004. Dasar - Dasar Statistika. Bandung: Alfabeta.

19. Sekaran. 2006. Research Methods for Business. Jakarta: Salemba Empat.

20. Sugiyono, 2008. Metode Penelitian Administrasi. Bandung: Alfabeta.

21. Suliyanto, 2005. Analisis Data dalam Aplikasi Pemasaran. Penerbit Ghalia Indonesia. 
22. Supranto, J. 2001. Pengukuran Tingkat Kepuasan Pelanggan Untuk Menaikkan Pangsa Pasar. Jakarta: Rineka Cipta.

23. Tahir M Nisar, Quang Nguyen, Dan Knox, Guru Prakash Prabhakar. 2017. customer satisfaction in the UK quick service restaurant industry: The influence of the tangible attributes of perceived service quality. British Food Journal. Vol. 120 Issue: 6, pp.12071222.

24. Tjiptono, Fandy. 2007. Strategi Pemasaran. Edisi ke dua. Yogyakarta: penerbit Andi.

25. Tjiptono, Fandy. 2006. Manajemen Pelayanan Jasa. Yogyakarta: Penerbit Andi.

26. Tjiptono, Fandy. 2005. Service Quality and Satisfaction. Edisi 2. Andi, Yogyakarta.

27. Tjiptono, Fandy. 2002. Manajemen Jasa. Cetakan II. Yogyakarta: Andi Offset.

28. Vinita Kaura, Ch. S. Durga Prasad, Sourabh Sharma. 2015. Service Quality, Service Convenience, Price and Fairness, Customer Loyalty, and the Mediating Role of Customer Satizfaction. International Journal of Bank Marketing. Vol. 33 Issue: 4, pp.404422.

29. Wahyuningrum. (2000). Buku Ajar Manajemen Fasilitas Pendidikan. Yogyakarta: FIP UNY. 